Textile \& Leather Review

\title{
An Investigation Approach for Assessing Challenges to Sustainable Consumption and Production Practices in the Leather Goods Industry
}

Md. Rashed-Ul-Islam, Laboni Begum, Afroza Hossain

How to cite: Islam MRU, Begum L, Hossain A. An Investigation Approach for Assessing Challenges to Sustainable Consumption and Production Practices in the Leather Goods Industry. Textile \& Leather Review. 2022; 5:85-102. https://doi.org/10.31881/TLR.2021.37

How to link: https://doi.org/10.31881/TLR.2021.37

Published: 24 February 2022 


\title{
An Investigation Approach for Assessing Challenges to Sustainable Consumption and Production Practices in the Leather Goods Industry
}

\author{
Md. Rashed-UI-ISLAM ${ }^{1 *}$, Laboni BEGUM ${ }^{1}$, Afroza HOSSAIN ${ }^{2}$ \\ ${ }^{1}$ Institute of Leather Engineering and Technology, University of Dhaka, Dhaka, Bangladesh \\ ${ }^{2}$ Department of Psychology, University of Dhaka, Dhaka, Bangladesh \\ *rashed.ilet@du.ac.bd \\ Article \\ https://doi.org/10.31881/TLR.2021.37 \\ Received 22 December 2021; Accepted 16 February 2022; Published 24 February 2022
}

\begin{abstract}
Sustainable consumption and production (SCP) practices in the leather goods industry is a new trend in the developing and developed countries and it is becoming more popular by the day. It is essential to introduce SCP practices for the production in the sub-sector of leather products in Bangladesh. The relevance of SCP activities to the leather goods industry is emphasized in this article. The previous work emphasised other industrial fields. Results reveal that the lack of technological up-gradation, lack of customer attitude and behaviour towards SCP, lack of incentives for/motivation of business organizations, lack of top management commitment, support, dedication and involvement, and customers who are attracted towards cheap products come under causal group challenges, which can help the decision makers formulate a policy for a successful implementation of SCP practices that will help achieve sustainable development goals.
\end{abstract}

\section{KEYWORDS}

leather goods industry, challenges, sustainable consumption and production, sustainability, supply chain sustainability, sustainable development goals

\section{INTRODUCTION}

In industry, production and consumption systems are based on conventional operating processes and using tools, methods and techniques that are typically not sustainable $[1,2]$. Therefore, Sustainable Consumption and Production (SCP) has emerged as a crucial domain for sustainable growth of organizations. The SCP is one of the Sustainable Development Goals (SDGs) that substantially contributes to the manufacturing industry's long-term viability. The Johannesburg Plan of implementation outlined an SCP concept in the year 2002 at the World Summit. Sustainability was defined in 1987 by the World Commission on Environment and Development. They described it as the "development that satisfies present needs without jeopardizing future generations", with the ability to satisfy their self-demand. Sustainability considers social, economic, and environmental elements that might help manufacturers move toward a more sustainable corporate environment [3-5]. For the sustainable growth of the industrial sector, successful supply chain activities are important. These have 
a reverse influence on the society and environment. As a result, techniques together with SCP can also additionally mitigate terrible environmental, communal, and monetary effects. Integrating SCP practices into supply chain networks can help businesses achieve sustainable development. SCP practices are adopted in the business organizations of developed countries in their manufacturing process. Adopting SCP methods in the production framework in developing nations, such as Bangladesh, is typically fraught with challenges like compliance, competitive pressure, customer pressure, and so on. As a result, Bangladesh has a significant opportunity to gain foothold in the global market by applying SCP principles in the manufacturing sector. The leather and footwear industries are two of Bangladesh's most rapidly increasing industrial sectors, because of the abundance of raw supplies, lower labour costs, and a pleasant working environment. The leather goods industry provides less to the global market than the leather and footwear industries [6,7]. As a result, in today's rapidly changing market, these industries need SCP practices in order to stay in business. In the leather products business, SCP techniques can help limit the use of hazardous substances, develop and strengthen the manufacturing system, and encourage consumers to purchase green products, all of which contributes to a positive image in the global market. A significant number of challenges in leather goods supply chain activities have made the implementation of SCP practices difficult. As a result, doing a thorough research into SCP in the leather goods business may aid in overcoming those obstacles by determining the true nature of each one. The DEMATEL technique was used in this study to find hurdles to SCP procedures and establish cause-effect links among identified difficulties in the leather products industry. We looked into some of the more recent literature. For instance, in the food supply chain, Govindan presented a conceptual framework for SCP activities [8]. Gupta et al. investigated the most major barriers to implementing environmentally friendly manufacturing in Indian manufacturing companies, Asdrubali et al. assessed global SCP policies and practices $[9,10]$. In order to better comprehend SCP and its value for supply chain operations, Vincent et al. looked at the research vacuum, challenges for a potential development analysis, and queries for upcoming studies and practices. A survey of the literature on SCP practices revealed that no research has been conducted in Bangladesh's leather goods industry. The following research questions were addressed in this research:

a) What are the challenges of sustainable consumption and production?

b) What are the interactions among identified challenges?

This research discovery makes a substantial contribution to the SCP literature in this regard. As a result, this study addresses the above-mentioned research issues, targeting the following goals: 
1. To determine the difficulties with SCP procedures in leather products business.

2. To figure out how the difficulties with SCP procedures are connected.

We analysed the existing literature to identify the most significant problems in SCP procedures. Then, using a set of questionnaires, five specialists from five respected and export-oriented leather goods enterprises in Bangladesh provided input. The DEMATEL technique was used to discover the interrelationships amongst the difficulties that had been highlighted. The key reason for using the DEMATEL technique was that it is an effective decision-making method capable of uncovering causeeffect links between components that neither the fuzzy analytical hierarchy process (F-AHP) nor the AHP can. As a result, this study will aid leather products factories in developing and improving strategies for deployment of SCP in supply chain operations. The following steps are carried out to conduct this research: a review of the literature on SCP is presented in the second section. The DEMATEL-based solution process is shown in the next section. The report's fourth section examines the method employed in the leather goods business. The research's conclusions are provided in the fifth section. The research outcome, consequences, drawbacks, and recommendations for further exploration are presented in the last part.

\section{LITERATURE REVIEW}

\section{Sustainable Consumption and Production (SCP)}

The SCP is well-defined as "the application of services and related products that interact to fundamental requirements and provide an improved way of life while limiting the use of environmental assets and harmful waste, including the discharges of refuse and contaminants over the life cycle of the service or product so as not to threaten the capacity of future generations," as defined by the Oslo Symposium in 1994. The term SCP was created for the first time with the ratification of the multiyear framework program (10 year) at the Rio Earth Summit $[1,11,12]$. In general, SCP refers to meeting all of a product's or service's needs while using the fewest possible resources and producing the least amount of waste and pollution. Hence, reduced wastage, efficient resource usage, implementation of a sustainable supply chain network in manufacturing, and increased employment opportunities can all help to alleviate poverty and contribute to sustainable development. Including sustainable manufacturing techniques and incorporating the sustainable supply chain management (SSCM) concept may help improve the success of sustainability implementation. The triple bottom line (TBL) approach is used in SSCM to effectively manage social, economic, and environmental challenges $[13,14]$. Manufacturing systems evolve throughout time in order to be competitive in today's global 
economy. As a result, since lower-income economies progress to middle-income ones, the earth is transforming in this way.

\section{DEMATEL Method}

In the field of decision science, DEMATEL is an effective, popular and powerful decision-making method. This technique may help to find the exact interrelationship between supply chain network variables. In decision science, DEMATEL approach helps in finding interactions among multiple factors through the digraph whereas other MCDM (multi-criteria decision-making) methods like AHP and Fuzzy-AHP are not able to compute the interactions among factors [15-17]. It is a popular and widely used MCDM technique which may classify variables into cause and effect categories. DEMATEL approach was practiced for various evaluation purposes by several researchers which indicates the popularity of this method. Stepwise, the following DEMATEL technique is explained $[18,19]$ :

Step one: getting the matrices for the first relationship

In the first stage, using Equation 1, with the help of the assessor, starting relationship matrices are built using numerical values. Using Equation 2, the average relation matrix is then constructed.

$$
\begin{aligned}
& X^{k}=\left[x_{i j}^{k}\right] \\
& x_{i j}=\frac{1}{H} \sum_{k=1}^{H} x_{i j}^{k}
\end{aligned}
$$

In this study, we wanted to examine the limits of SCP procedures, using the following verbal expressions (Table 1 ).

Table 1. Numeric values expressed verbally

\begin{tabular}{lc}
\hline Linguistic scale & Favourability index in evaluation \\
\hline 0 & Totally unfavourable \\
2 & Very unfavourable \\
4 & Low favourable \\
6 & Medium favourable \\
8 & Highly favourable \\
10 & Extremely highly favourable
\end{tabular}

Intermediate scores 1, 3, 5, 7 and 9 can be used as well if necessary 
Step two: creating a structured direct relation grid $N$

Using the following Equation 3, make direct relation grid

$$
N=M \times s
$$

Here, $s$ is calculated by the given equation:

$$
S=\min \left[\frac{1}{\sum_{j=1}^{n}\left|X_{i j}\right|}\right], \frac{1}{\sum_{i=1}^{n}\left|X_{i j}\right|}
$$

Step three: building a complete relation matrix $T$ with the support of the following Equation 5 , with the notation I denoting the identity grid

$$
T=N+N^{2}+N^{3}+\cdots+\sum_{i=1}^{\infty} N^{i}=N(I-N)^{-1}
$$

Step four: estimating the cumulative impact and significance in this stage with the help of Equations 6,

\section{7,8 and 9}

The symbols $P i$ and $E i$ stand for prominence and cumulative impact, respectively.

$$
\begin{aligned}
& R i=\sum_{j=1}^{n} t_{i j} \forall i \\
& C j=\sum_{j=1}^{n} t_{i j} \forall j \\
& P i=\{R i+C j \mid i=j\} \\
& E i=\{R i-C j \mid i=j\}
\end{aligned}
$$

\section{RESULTS AND DISCUSSION}

In the leather industry sector of Bangladesh, the leather goods business is one of the most forwarding contributors with the most potential for earning foreign currency, looking at the 2017-2018 financial year. It is clear that the leather goods industry has an important role in Bangladesh's economic growth. Sustainable production practices are, therefore, important in leather goods industries for enhancing the activities and the productivity of the supply chain and for taking advantage of the dynamic world market. In this context, the SCP activities will help foster and advance a more effective and sustainable supply chain network for the leather goods industry. In this study, we are trying to prioritize the 
obstacles in the supply chain of leather goods to incorporating SCP. We have divided the experimental steps of this analysis into two stages. These are described in the subsequent diagram.

Phase 1: the leading obstacles to SCP procedure were established in this step. Initially, from the related literature given in table A1 several significant challenges to SCP procedures in the leather products sector were established. We searched multiple academic databases for this purpose, including Science Direct, Google Scholar, Scopus, EBSCO and Web of Science. SSCM challenges and obstacles for the green supply chain management can be found by utilizing keywords like "constraints to SCP practice", and "SSCM impediments to the green supply chain management" (GSCM). Throughout this procedure, five specialists from five reputable and export-oriented leather goods firms were picked to secure the best possible outcome. We picked 5 experts from 5 sampled leather goods industries for further generalization including 2 large-sized leather goods industries, 2 medium sized leather goods industry, and another 1 small-sized leather goods industry. Experts from the supply chain, human resources, engineering, quality management and logistics department were allocated respectively. They have substantial expertise in SCP, with 15 years of experience working in the appropriate fields. The expert responses were gathered through the distribution of survey questionnaires (Appendix 1). Finally, based on the input of experts, which is illustrated in Table 2, the 10 most significant problems were listed.

Table 2. Challenges for the SCP implementation

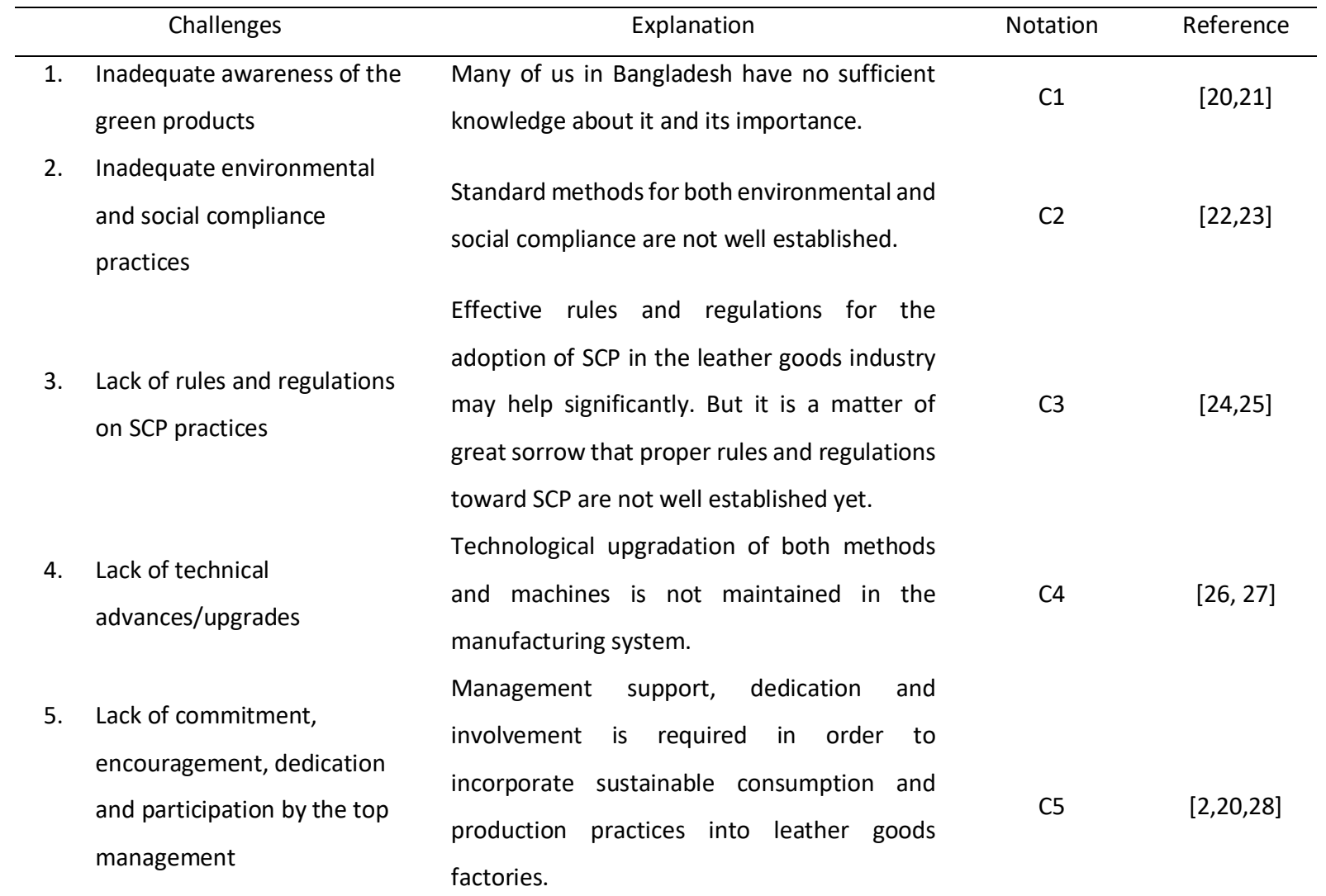




\begin{tabular}{|c|c|c|c|c|}
\hline & Challenges & Explanation & Notation & Reference \\
\hline 6. & $\begin{array}{l}\text { Lack of customer attitude and } \\
\text { action towards SCP }\end{array}$ & $\begin{array}{l}\text { Customer's interest towards SCP is important } \\
\text { for implementing it in the manufacturing } \\
\text { process. }\end{array}$ & C6 & [29] \\
\hline 7. & $\begin{array}{l}\text { Motivational distance among } \\
\text { consumers }\end{array}$ & $\begin{array}{l}\text { The consumer's motivation for supporting SCP } \\
\text { practices is absent, which is also one of the } \\
\text { significant challenges. }\end{array}$ & $\mathrm{C7}$ & {$[30,31]$} \\
\hline 8. & $\begin{array}{l}\text { Customers attracted to cheap } \\
\text { products }\end{array}$ & $\begin{array}{l}\text { Most customers tend to purchase cheaper car } \\
\text { models rather than investing in more effective } \\
\text { or greener alternatives because these vehicles } \\
\text { mostly carry higher price tags. }\end{array}$ & $\mathrm{C} 8$ & {$[32,33]$} \\
\hline 9. & $\begin{array}{l}\text { Lack of organizational } \\
\text { incentives / motivations }\end{array}$ & $\begin{array}{l}\text { No visible benefit to the organization for } \\
\text { following SCP in the manufacturing process. }\end{array}$ & C9 & {$[34,35]$} \\
\hline 10. & $\begin{array}{l}\text { Low recyclability of some } \\
\text { wastages }\end{array}$ & $\begin{array}{l}\text { Some wastages from the leather goods } \\
\text { industry cannot be fully recycled due to the } \\
\text { method and financial constraint. }\end{array}$ & C10 & [36-38] \\
\hline
\end{tabular}

Phase 2: in this part, DEMATEL technique is used to identify the interactions between the established SCP challenges in Bangladesh's leather goods industry. In the four-step method, DEMATEL was used to classify the connections between the problems found.

Step 1: The textual value was utilized to discover the direct-relation framework $Z$ in this stage. The linguistic quantitative value is supplied in Table 1 , and the direct-relation framework $Z$, which was derived using Equation 1, is given in Table 3. Table 4 shows the average composite relationship, which is calculated using Equation 2.

Table 3. First relation grid $\left(x_{i j}^{k}\right)$ among the established difficulties

\begin{tabular}{ccccccccccc}
\hline Expert 1 & $C 1$ & $C 2$ & $C 3$ & $C 4$ & $C 5$ & $C 6$ & $C 7$ & $C 8$ & $C 9$ & C10 \\
\hline C1 & 0 & 10 & 7 & 5 & 7 & 1 & 10 & 9 & 10 & 8 \\
C2 & 5 & 0 & 1 & 6 & 9 & 9 & 5 & 2 & 6 & 1 \\
C3 & 3 & 7 & 0 & 6 & 9 & 1 & 3 & 3 & 2 & 4 \\
C4 & 9 & 1 & 8 & 0 & 3 & 7 & 10 & 5 & 3 & 10 \\
C5 & 5 & 9 & 4 & 2 & 0 & 4 & 4 & 9 & 5 & 10 \\
C6 & 8 & 1 & 9 & 4 & 2 & 0 & 2 & 2 & 5 & 10 \\
C7 & 2 & 3 & 8 & 8 & 5 & 8 & 0 & 7 & 0 & 7 \\
C8 & 10 & 4 & 2 & 3 & 2 & 4 & 7 & 0 & 9 & 7 \\
C9 & 1 & 5 & 6 & 1 & 3 & 8 & 2 & 5 & 0 & 5 \\
C10 & 7 & 3 & 2 & 7 & 3 & 9 & 2 & 10 & 4 & 0 \\
\hline
\end{tabular}


Table 4. Average relation matrix $\left(x_{i j}=\frac{1}{H} \sum_{k=1}^{H} x_{i j}^{k}\right)$

\begin{tabular}{ccccccccccc}
\hline Challenges & C1 & C2 & C3 & C4 & C5 & C6 & C7 & C8 & C9 & C10 \\
\hline C1 & 0 & 6.6 & 5.6 & 4 & 6.2 & 4.4 & 7 & 4.4 & 5.8 & 5.4 \\
C2 & 3 & 0 & 4.2 & 3.2 & 7.2 & 4.6 & 6.2 & 4 & 4.6 & 5.4 \\
C3 & 5.6 & 5.2 & 0 & 4.4 & 4.8 & 3.4 & 6.8 & 5.6 & 3.2 & 5.8 \\
C4 & 5.8 & 5.8 & 5.4 & 0 & 7.4 & 7.8 & 6 & 8.8 & 5.8 & 4.8 \\
C5 & 5 & 4.8 & 6.4 & 6 & 0 & 4.4 & 6 & 4.6 & 6.2 & 4.2 \\
C6 & 5 & 6 & 7.4 & 5.6 & 6 & 0 & 5.2 & 3.8 & 3.8 & 8.4 \\
C7 & 4.8 & 5 & 5.2 & 5.2 & 5.2 & 6.8 & 0 & 5.4 & 4.8 & 6.2 \\
C8 & 7.2 & 4.8 & 5.6 & 3.2 & 3.4 & 5.2 & 6 & 0 & 4.6 & 5.2 \\
C9 & 6.2 & 6 & 5.2 & 3.4 & 4.4 & 5.2 & 6.2 & 3.6 & 0 & 4.8 \\
C10 & 7 & 3 & 3.2 & 6.6 & 3 & 5.8 & 4.6 & 4.8 & 5.2 & 0 \\
\hline
\end{tabular}

Step two: The normalized direct-relation grid $N$ was generated in this phase, using Equations 3 and 4 , and is shown in Table 5.

Table 5. Normalized initial grid (N)

\begin{tabular}{cllllllllll}
\hline Matrix N & C1 & C2 & C3 & C4 & C5 & C6 & C7 & C8 & C9 & C10 \\
\hline C1 & 0.0000 & 0.1146 & 0.0972 & 0.0694 & 0.1076 & 0.0764 & 0.1215 & 0.0764 & 0.1007 & 0.0938 \\
C2 & 0.0521 & 0.0000 & 0.0729 & 0.0556 & 0.1250 & 0.0799 & 0.1076 & 0.0694 & 0.0799 & 0.0938 \\
C3 & 0.0972 & 0.0903 & 0.0000 & 0.0764 & 0.0833 & 0.0590 & 0.1181 & 0.0972 & 0.0556 & 0.1007 \\
C4 & 0.1007 & 0.1007 & 0.0938 & 0.0000 & 0.1285 & 0.1354 & 0.1042 & 0.1528 & 0.1007 & 0.0833 \\
C5 & 0.0868 & 0.0833 & 0.1111 & 0.1042 & 0.0000 & 0.0764 & 0.1042 & 0.0799 & 0.1076 & 0.0729 \\
C6 & 0.0868 & 0.1042 & 0.1285 & 0.0972 & 0.1042 & 0.0000 & 0.0903 & 0.0660 & 0.0660 & 0.1458 \\
C7 & 0.0833 & 0.0868 & 0.0903 & 0.0903 & 0.0903 & 0.1181 & 0.0000 & 0.0938 & 0.0833 & 0.1076 \\
C8 & 0.1250 & 0.0833 & 0.0972 & 0.0556 & 0.0590 & 0.0903 & 0.1042 & 0.0000 & 0.0799 & 0.0903 \\
C9 & 0.1076 & 0.1042 & 0.0903 & 0.0590 & 0.0764 & 0.0903 & 0.1076 & 0.0625 & 0.0000 & 0.0833 \\
C10 & 0.1215 & 0.0521 & 0.0556 & 0.1146 & 0.0521 & 0.1007 & 0.0799 & 0.0833 & 0.0903 & 0.0000 \\
\hline
\end{tabular}


Step three: For the established total relation grid $T$, shown in Table 6, Equation 5 was used.

Table 6. Complete relationship grid ( $T$ )

\begin{tabular}{cllllllllll}
\hline Challenges & C1 & C2 & C3 & C4 & C5 & C6 & C7 & C8 & C9 & C10 \\
\hline C1 & 0.4178 & 0.5031 & 0.4963 & 0.4247 & 0.5007 & 0.4745 & 0.5626 & 0.4523 & 0.4677 & 0.5115 \\
C2 & 0.4145 & 0.3468 & 0.4235 & 0.3678 & 0.4620 & 0.4253 & 0.4911 & 0.3967 & 0.4014 & 0.4563 \\
C3 & 0.4731 & 0.4489 & 0.3735 & 0.4011 & 0.4462 & 0.4273 & 0.5220 & 0.4400 & 0.3986 & 0.4822 \\
C4 & 0.5780 & 0.5561 & 0.5614 & 0.4166 & 0.5820 & 0.5886 & 0.6204 & 0.5779 & 0.5274 & 0.5721 \\
C5 & 0.4883 & 0.4677 & 0.4986 & 0.4445 & 0.3937 & 0.4651 & 0.5372 & 0.4478 & 0.4638 & 0.4832 \\
C6 & 0.5145 & 0.5076 & 0.5368 & 0.4638 & 0.5122 & 0.4185 & 0.5524 & 0.4597 & 0.4519 & 0.5714 \\
C7 & 0.4933 & 0.4766 & 0.4884 & 0.4406 & 0.4826 & 0.5073 & 0.4494 & 0.4650 & 0.4497 & 0.5215 \\
C8 & 0.4990 & 0.4470 & 0.4655 & 0.3849 & 0.4284 & 0.4549 & 0.5137 & 0.3517 & 0.4206 & 0.4776 \\
C9 & 0.4813 & 0.4630 & 0.4581 & 0.3868 & 0.4426 & 0.4534 & 0.5147 & 0.4093 & 0.3454 & 0.4698 \\
C10 & 0.4881 & 0.4125 & 0.4222 & 0.4274 & 0.4148 & 0.4574 & 0.4827 & 0.4226 & 0.4224 & 0.3848 \\
\hline
\end{tabular}

Step 4: Finally, the impact and value were determined with the help of Equations 6, 7, 8 and 9. The cause-effect relationship between the established SCP challenges is illustrated in Table 7.

Table 7. The cause-effect relation among the identified SCP challenges

\begin{tabular}{lcccccc}
\hline \multirow{2}{*}{ Challenges } & \multicolumn{4}{c}{ Cause-Effect Relationship } & & \\
\cline { 2 - 7 } & Sum of row $\left(r_{i}\right)$ & Sum of column $\left(c_{\mathrm{j}}\right)$ & $P i=r_{i}+c_{j}$ & $E_{i}=r_{i}-c_{j}$ & Rank & Impact \\
\hline C1 & 4.8113 & 4.8481 & 9.6594 & -0.0369 & 4 & Effect \\
C2 & 4.1854 & 4.6294 & 8.8148 & -0.4440 & 9 & Effect \\
C3 & 4.4129 & 4.7243 & 9.1372 & -0.3114 & 7 & Effect \\
C4 & 5.5806 & 4.1582 & 9.7388 & 1.4225 & 2 & Cause \\
C5 & 4.6900 & 4.6652 & 9.3552 & 0.0248 & 5 & Cause \\
C6 & 4.9888 & 4.6725 & 9.6612 & 0.3163 & 3 & Cause \\
C7 & 4.7744 & 5.2462 & 10.0206 & -0.4718 & 1 & Effect \\
C8 & 4.4432 & 4.4230 & 8.8662 & 0.0202 & 8 & Cause \\
C9 & 4.4244 & 4.3488 & 8.7733 & 0.0756 & 10 & Cause \\
C10 & 4.3349 & 4.9302 & 9.2651 & -0.5953 & 6 & Effect \\
\hline
\end{tabular}




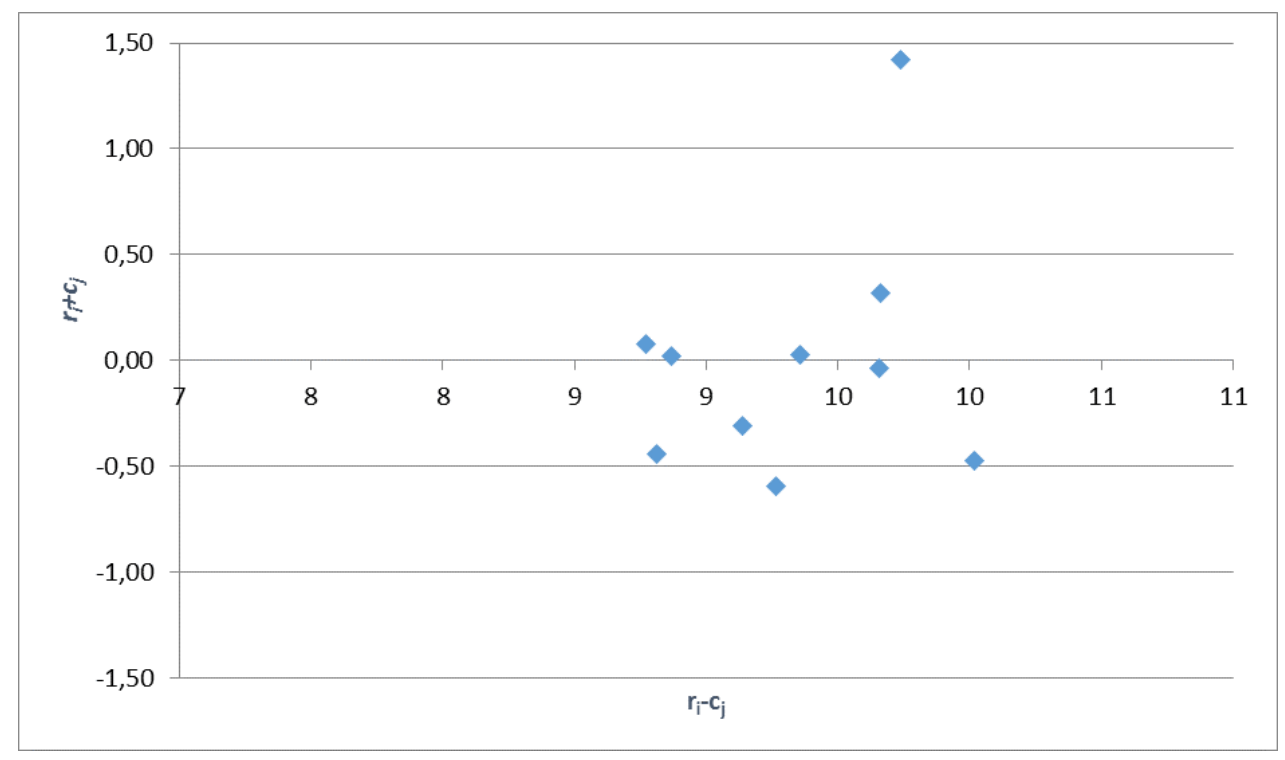

Figure 1. The cause-effect relationship among the identified challenges for SCP

Among the described challenges for SCP, the Ri-Cj's positive value on the relationship digraph reveals the causal difficulties. The following is a list of the challenges, in decreasing order, as indicated in this study: lack of technical advances/upgrades (C4)> lack of customer attitude and action towards SCP (C6)> lack of organizational incentives/motivations (C9)> lack of commitment, encouragement, dedication and participation by the top management (C5)> customers attracted to cheap goods (C8). It is evident that the lack of technical advances/upgrades (C4) is rated as the key contributing challenge for SCP practices in leather goods industries owing to substantial progressive impact on other challenges listed. Other obstacles will then be progressively strengthened by reducing the absence of technical advances/upgrades (C4). SCP requires considerable changes and modification in existing methods and machineries with the change of time. Modern and standard latest technology involvement will enhance the implementation of SCP in manufacturing. The second most significant challenge to SCP practice is the lack of customer attitude and action towards SCP (C6). The customer plays an important role in the implementation of SCP in the supply chain operation. If the customer had a strong concept of the importance of SCP practice and was bound to the manufacturer for sustainable production, it would be more effective to practice sustainable production, through which the industry could improve their current practice and also minimize the effect of other challenges.

The lack of organizational incentives/motivations (C9) secured the 3rd position among the causal challenges. There are no rewards or visible benefit to the organization for following the SCP practice in manufacturing. That is why many companies are indifferent about it. The lack of top management commitment, support, dedication and involvement (C5) is another important challenge to the SCP practice which got the 4 th position among the causal challenges in this analysis. Hence, improving the 
top management level, support and commitment to employing SCP and direct involvement in it may loosen the barriers to sustainability. The last and 5th challenge is that the customers are attracted towards cheap products (C8), referring to the fact that many customers are primarily concerned about the cost and not the quality of the product. Therefore, it is also an important causal challenge that needs to be worked on in order to enable sustainable development in the business activities as it may affect the other challenges for SCP.

It is important to understand the impact of each effect group challenges for SCP to be applied in the production chain. On the basis of the negative value of $\mathrm{Ri}-\mathrm{Cj}$ in Table 6, the subsequent impact group difficulties can be identified in the decreasing order: inadequate awareness of the green product (C1) $>$ absence of norms and restrictions on SCP practices (C3) > inadequate environmental and social compliance practices (C2) > motivational distance among consumers $(\mathrm{C} 7)>$ low recyclability of some wastages (C10).

Inadequate awareness of the green product (C1) has earned a less negative score in the impact category. Causal challenges are closer to this challenge. Thus, other causal challenges will not greatly affect this challenge. As improving this task can push the entire system towards SCP practices, insufficient awareness of SCP practices (C3) is close to causal difficulties. The absence of rules and regulations on SCP activities entered the second position among the problems of the impact community that can be reduced by enhancing the causal difficulties. It is an important challenge because its proper utilization can bound the manufacturer to follow SCP for creating sustainability in an uncertain environment. The third effect group challenge towards SCP is poor environmental and social compliance practices (C2), which indicates that the leather goods industry is not trying to prevent the environment and society from being polluted by the wastage they produce daily. This effect can also be reduced by appropriately addressing causal challenges. One of the impact problems is the motivational divide among consumers and it can be resolved by properly implementing green product promotions, advertising their significance, offering incentives to the manufacturing companies etc. Therefore, by addressing the causal challenge, this impact group challenge may be greatly affected. Low recyclability of some wastes (C10) has been placed last in the impact community, and all identified causal difficulties can have a significant impact on it. By recognizing the link between the issues stated, five of which were causal and five of which were effects, this study could strongly benefit the leather goods industry. Causal challenges often serve as critical driving challenges, so these challenges are first and foremost met properly in order to create a sustainable climate in this sector, so the impact group challenges can be immediately mitigated. 


\section{CONCLUSION}

SCP has an esteemed influence on the development of a sustainable manufacturing environment in leather goods factories. The SCP practices may drive the leather goods sector of Bangladesh to its culmination of sustainable development. The findings of this work indicate that the decision-makers in the leather goods industry should consider these identified causal challenges carefully, because dealing with then will help this type of companies in implementing the SCP practices. The problems of the impact community have a less negative meaning, which suggests a minimal effect on the practice of SCP. These problems can often be more powerful and influential. The result would also assist the decision-makers in formulating both short- and long-term strategies. Fortunately, this research will assist the decision-makers in determining the original existence of all the challenges for incorporating SCP practices found in the leather goods manufacturing activities. The following are the study's major contributions:

1. This study showed the particular case of the leather goods industry in order to examine the most pressing problems of applying SCP practices.

2. By exploring numerous literature reviews and expert perspectives, ten main obstacles to SCP practices have been prioritized. To determine these obstacles, industrial managers and teachers from the leather academic institute were involved.

3. A powerful DEMATEL tool was utilized to determine the interaction among the recognized barriers to SCP procedures when it comes to the leather supply network.

Therefore, the findings of this study may be requested to assist business owners and decision-makers in formulating strategic corporate strategy to mitigate the causal obstacles of the effective adoption of SCP activities in the current supply network. Nevertheless, we evaluated only 10 challenges to the SCP practice though the DEMATEL approach in order to calculate the interrelationship among those selected challenges, which may be the limitation of this study. Hopefully, more obstacles will be considered for the analysis of their interrelationship in the sustainability establishment in the leather goods industry and DEMATEL's extension can also be utilised in future investigations.

\section{APPENDIX}

\section{Survey questionnaires}

Q.1: In the supply chain of leather goods, what is your position and experience?

Q.2: Do you understand what it means to implement sustainable consumption and production (SCP)?

Q.3: From the background of the leather goods industry, please pick the most relevant challenges for SCP from Table A1. 
Table A1: Primary survey on SCP issues

\begin{tabular}{|c|c|c|}
\hline SL. No. & $\begin{array}{l}\text { Challenges to implementing sustainable consumption and production (SCP) in leather } \\
\text { goods industries }\end{array}$ & YES/NO \\
\hline 1 & Focus on production cost reduction & \\
\hline 2 & Lack of resources and capabilities & \\
\hline 3 & Poor industrial infrastructure & \\
\hline 4 & Lack of positive brand image & \\
\hline 5 & New Concept for many Bangladeshi & \\
\hline 6 & Absence of market information of green products & \\
\hline 7 & Limited knowledge on environmental and social compliance & \\
\hline 8 & Lack of technological advances/upgrades to SCP implementation & \\
\hline 9 & Lack of sufficient techniques, instruments and techniques for safer production practices & \\
\hline 10 & Lack of guidelines on SCP procedure and legislation & \\
\hline 11 & Lack of organisational incentives/motivations & \\
\hline 12 & Poor enforcement & \\
\hline 13 & $\begin{array}{l}\text { Lack of the engagement of the top management, encouragement, devotion and } \\
\text { participation in the implementation of SCP }\end{array}$ & \\
\hline 14 & Inadequate training facility on SCP & \\
\hline 15 & No visible benefit for the company & \\
\hline 16 & Falling exports & \\
\hline 17 & Lack of ethical and safe practice promotion & \\
\hline 18 & Customers attracted towards cheap products & \\
\hline 19 & Consumer resistance towards activities of sustainable development & \\
\hline 20 & Lack of customer attitude and behaviour towards SCP & \\
\hline 21 & Uncertainty about the market demand & \\
\hline 22 & Motivational gap among consumers & \\
\hline 23 & Poor linkage and coordination among the leading firms & \\
\hline 24 & Financial constraints & \\
\hline 25 & $\begin{array}{l}\text { Lack of integrated processes when designing and implementing policies, initiatives and } \\
\text { strategies for sustainable development }\end{array}$ & \\
\hline 26 & Lack of attention paid to the growth of SCP theories and grounded research & \\
\hline 27 & Lack of supply chain network design flexibility & \\
\hline 28 & Lack of a strong public and non-government view of the evolving SCP challenges & \\
\hline 29 & Integration of social, environmental, and economic advantages & \\
\hline 30 & Non recyclability of some wastages & \\
\hline
\end{tabular}


Q.4 Please use linguistic value to fill up the first direct relation grids.

\begin{tabular}{|c|c|c|c|c|c|c|c|c|c|c|}
\hline Challenges & $\mathrm{C} 1$ & $\mathrm{C} 2$ & C3 & C4 & $\mathrm{C} 5$ & C6 & C7 & $\mathrm{C} 8$ & C9 & $\mathrm{C} 10$ \\
\hline \multicolumn{11}{|l|}{$\mathrm{C} 1$} \\
\hline \multicolumn{11}{|l|}{ C2 } \\
\hline \multicolumn{11}{|l|}{ C3 } \\
\hline \multicolumn{11}{|l|}{ C4 } \\
\hline \multicolumn{11}{|l|}{ C5 } \\
\hline \multicolumn{11}{|l|}{ C6 } \\
\hline \multicolumn{11}{|l|}{$\mathrm{C7}$} \\
\hline \multicolumn{11}{|l|}{$\mathrm{C} 8$} \\
\hline \multicolumn{11}{|l|}{ C9 } \\
\hline $\mathrm{C} 10$ & & & & & & & & & & \\
\hline
\end{tabular}

\section{Author Contributions}

Conceptualization - Islam MRU, Begum L and Hossain A; methodology - Islam MRU and Begum L; formal analysis - Islam MRU and Begum L; investigation - Islam MRU and Hossain A; resources - Islam MRU and Hossain A; writing-original draft preparation - Islam MRU and Begum L; writing-review and editing - Islam MRU, Begum L and Hossain A; visualization - Islam MRU, Begum L and Hossain A; supervision - Islam MRU and Hossain A. All authors have read and agreed to the published version of the manuscript.

\section{Conflicts of Interest}

The authors declare no conflict of interest.

\section{Funding}

This research received no external funding.

\section{Acknowledgements}

The authors would like to thanks the relveant leather goods industry to give the access to collect the data. 


\section{REFERENCES}

[1] Pogutz S, Micale V. Sustainable consumption and production: An effort to reconcile the determinants of environmental impact. Society and Economy. 2011; 33(1):29-50. https://doi.org/10.1556/socec.33.2011.1.5

[2] Welch D. Sustainable Production and Consumption. In: Wright JD, editor. International Encyclopedia of the Social \& Behavioral Sciences [Internet]. Elsevier; 2015. p. 839-844. https://doi.org/10.1016/B978-0-08-097086-8.91054-7

[3] Briceno T, Stagl S. The role of social processes for sustainable consumption. Journal of Cleaner Production. 2006; 14(17):1541-1551. https://doi.org/10.1016/j.jclepro.2006.01.027

[4] Lorek S, Spangenberg JH. Sustainable consumption within a sustainable economy - beyond green growth and green economies. Journal of Cleaner Production. 2014; 63:33-44. https://doi.org/10. 1016/j.jclepro.2013.08.045

[5] Vergragt PJ, Dendler L, de Jong M, Matus K. Transitions to sustainable consumption and production in cities. Journal of Cleaner Production. 2016; 134(Part A):1-12. https://doi.org/10.10 16/j.jclepro.2016.05.050

[6] Moktadir MA, Rahman T, Rahman MH, Ali SM, Paul SK. Drivers to sustainable manufacturing practices and circular economy: A perspective of leather industries in Bangladesh. Journal of Cleaner Production. 2018; 174:1366-1380. https://doi.org/10.1016/j.jclepro.2017.11.063

[7] Paul H, Antunes APM, Covington AD, Evans P, Phillips PS. Bangladeshi Leather Industry: An Overview of Recent Sustainable Developments. Journal of the Society of Leather Technologists and Chemists. 2013; 97(1):25-32.

[8] Govindan K. Sustainable consumption and production in the food supply chain: A conceptual framework. International Journal of Production Economics. 2018; 195:419-431. https://doi.org/1 $\underline{0.1016 / j . i j p e .2017 .03 .003}$

[9] Gupta S, Dangayach GS, Singh AK, Meena ML, Rao PN. Implementation of sustainable manufacturing practices in Indian manufacturing companies. Benchmarking: An International Journal. 2018; 25(7):2441-2459. https://doi.org/10.1108/BIJ-12-2016-0186

[10] Asdrubali F, D'Alessandro F, Schiavoni S. A review of unconventional sustainable building insulation materials. Sustainable Materials and Technologies. 2015; 4:1-17. https://doi.org/10.1 $\underline{016 / \text { i.susmat.2015.05.002 }}$

[11] Lebel L, Lorek S. Enabling Sustainable Production-Consumption Systems. Annual Review of Environment and Resources. 2008; 33:241-275. https://doi.org/10.1146/annurev.energy.33.022 $\underline{007.145734}$ 
[12] Linton JD, Klassen R, Jayaraman V. Sustainable supply chains: An introduction. Journal of Operations Management. 2007; 25(6):1075-1082. https://doi.org/10.1016/j.jom.2007.01.012

[13] Lewis E, Chamel O, Mohsenin M, Ots E, White ET. Sustainaspeak [Internet]. New York: Routledge; 2018. Triple Bottom Line; 348. https://doi.org/10.4324/9781315270326-190

[14] Vanclay F. The Triple Bottom Line and Impact Assessment: How do TBL, EIA, SIA, SEA AND EMS Relate to Each Other? Journal of Environmental Assessment Policy and Management. 2004; 6(3):265-288. https://doi.org/10.1142/s1464333204001729

[15] Falatoonitoosi E, Leman Z, Sorooshian S, Salimi M. Decision-making trial and evaluation laboratory. Research Journal of Applied Sciences, Engineering and Technology. 2013; 5(13):34763480. https://doi.org/10.19026/rjaset.5.4475

[16] Hsu CW, Kuo TC, Chen SH, Hu AH. Using DEMATEL to develop a carbon management model of supplier selection in green supply chain management. Journal of Cleaner Production. 2013; 56:164-172. https://doi.org/10.1016/i.jclepro.2011.09.012

[17] Lee YC, Li ML, Yen TM, Huang TH. Analysis of adopting an integrated decision making trial and evaluation laboratory on a technology acceptance model. Expert Systems with Applications. 2010; 37(2):1745-1754. https://doi.org/10.1016/i.eswa.2009.07.034

[18] Sumrit D, Anuntavoranich P. Using DEMATEL Method to Analyze the Causal Relations on Technological Innovation Capability Evaluation Factors in Thai Technology-Based Firms. International Transaction Journal of Engineering, Management, \& Applied Sciences \& Technologies. 2013; 4(2):81-103.

[19] Uygun O, Kacamak H, Kahraman UA. An integrated DEMATEL and Fuzzy ANP techniques for evaluation and selection of outsourcing provider for a telecommunication company. Computers \& Industrial Engineering. 2015; 86:137-146. https://doi.org/10.1016/i.cie.2014.09.014

[20] Moktadir MA, Rahman T, Ali SM. Critical Success Factors in Implementing Green Supply Chain Management Practices in Footwear Industry in Bangladesh - An Interpretive Structural Modeling Approach. In: Proceeding of 1st International Conference on Buinsess and Management (ICBM); 20-21 September 2017; Dhaka, Bangladesh. Dhaka: 2017. p. 447-452.

[21] Ali K, Moktadir MA, Shaikh AA, Deb AK, Rashed-UI-Islam M. Challenges Evaluation for Adoption of SCP Practices in Footwear Industry of Bangladesh: A DEMATEL Approach. Journal of Operations and Strategic Planning. 2019; 1(2):168-184. https://doi.org/10.1177/2516600×18812984

[22] Hakkinen T, Belloni K. Barriers and drivers for sustainable building. Building Research \& Information. 2011; 39(3):239-255. https://doi.org/10.1080/09613218.2011.561948 
[23] Harris F, Roby H, Dibb S. Sustainable clothing: challenges, barriers and interventions for encouraging more sustainable consumer behaviour. International Journal of Consumer Studies. 2016; 40(3):309-318. https://doi.org/10.1111/ijcs.12257

[24] Farla J, Alkemade F, Suurs RAA. Analysis of barriers in the transition toward sustainable mobility in the Netherlands. Technological Forecasting and Social Change. 2010; 77(8):1260-1269. https://doi.org/10.1016/j.techfore.2010.03.014

[25] Sajjad A, Eweje G, Tappin D. Sustainable Supply Chain Management: Motivators and Barriers. Business Strategy and the Environment. 2015; 24(7):643-655. https://doi.org/10.1002/bse.1898

[26] Ali SM, Arafin A, Moktadir MA, Rahman T, Zahan N. Barriers to Reverse Logistics in the Computer Supply Chain Using Interpretive Structural Model. Global Journal of Flexible Systems Management. 2018; 19:53-68. https://doi.org/10.1007/s40171-017-0176-2

[27] Moktadir A, Rahman T, Jabbour CJC, Ali SM, Kabir G. Prioritization of drivers of corporate social responsibility in the footwear industry in an emerging economy: A fuzzy AHP approach. Journal of Cleaner Production. 2018; 201:369-381. https://doi.org/10.1016/i.jclepro.2018.07.326

[28] Moktadir MA, Rahman T, Ali SM. Examining Critical Success Factors to Humanitarian Supply Chain of Bangladesh: An Interpretive Structural Modeling (ISM) Approach. In: Proceeding of 3rd International Conference on Mechanical, Industrial and Materials Engineering (ICMIME2017); 2830 December 2017; Faculty of Mechanical Engineering, RUET, Rajshahi, Bangladesh. Rajshahi: 2017. p. 1-6.

[29] Niinimaki K, Hassi L. Emerging design strategies in sustainable production and consumption of textiles and clothing. Journal of Cleaner Production. 2011; 19(16):1876-1883. https://doi.org/10. 1016/j.jclepro.2011.04.020

[30] Dubey R, Gunasekaran A, Papadopoulos T, Childe SJ. Green supply chain management enablers: Mixed methods research. Sustainable Production and Consumption. 2015; 4:72-88. https://doi.o rg/10.1016/i.spc.2015.07.001

[31] Peattie K. Green Consumption: Behavior and Norms. Annual Review of Environment and Resources. 2010; 35:195-228. https://doi.org/10.1146/annurev-environ-032609-094328

[32] Schafer M, Bamberg S. Sustainable Consumption and Production: Framework for Action. In: 2nd Conference of the Sustainable Consumption and Production Resarch Exchange (SCORE!) Network; 2008.

[33] Tseng ML, Chiu ASF, Tan RR, Siriban-Manalang AB. Sustainable consumption and production for Asia: sustainability through green design and practice. Journal of Cleaner Production. 2013; 40:15. https://doi.org/10.1016/j.jclepro.2012.07.015

[34] Biswas A, Roy M. Green products: an exploratory study on the consumer behaviour in emerging 
economies of the East. Journal of Cleaner Production. 2015; 87:463-468. https://doi.org/10.101 6/j.jclepro.2014.09.075

[35] Brizga J, Mishchuk Z, Golubovska-Onisimova A. Sustainable consumption and production governance in countries in transition. Journal of Cleaner Production. 2014; 63:45-53. https://doi. org/10.1016/i.jclepro.2013.06.011

[36] Doyle R, Davies AR. Towards sustainable household consumption: exploring a practice oriented, participatory backcasting approach for sustainable home heating practices in Ireland. Journal of Cleaner Production. 2013; 48:260-271. https://doi.org/10.1016/j.jclepro.2012.12.015

[37] Fischer D, Stanszus L, Geiger S, Grossman P, Schrader U. Mindfulness and sustainable consumption: A systematic literature review of research approaches and findings. Journal of Cleaner Production. 2017; 162:544-558. https://doi.org/10.1016/i.jclepro.2017.06.007

[38] Jeswani HK, Burkinshaw R, Azapagic A. Environmental sustainability issues in the food-energywater nexus: Breakfast cereals and snacks. Sustainable Production and Consumption. 2015; 2:1728. https://doi.org/10.1016/i.spc.2015.08.001 